\title{
Effect of the quality of health care on permanent inability secondary to femoral fractures due to occupational accidents
}

\author{
Santiago Salinas-Tovar, M.D.,(1) Sandra Reyes-Frausto, M.D., M.Sc., ${ }^{(2)}$ \\ Alberto Aguilar-Salinas, M.D., M.Sc., ${ }^{(1)}$ Alberto López-Marmolejo, M.D., ${ }^{(1)}$ \\ Blanca E. Hernández-Leyva M.D., ${ }^{(3)}$ Pablo López-Rojas, M.D., M.Sc. ${ }^{(1)}$
}

\begin{abstract}
Salinas-Tovar S, Reyes-Frausto S, Aguilar-Salinas A, López-Marmolejo A,

Hernández-Leyva BE, López-Rojas $P$.

Effect of the quality of health care

on permanent inability secondary to femoral fractures due to occupational accidents.

Salud Publica Mex 2001;43:108-112.

The English version of this paper

is available at: http://www.insp.mx/salud/index.html
\end{abstract}

\begin{abstract}
A bstract
Objective. To construct and validate an indicator for evaluating the quality of care for femoral fractures, and to assess the contribution of the quality of health care as a determinant of partial permanent inability secondary to femoral fractures due to occupational accidents. Materials and methods. The study was conducted from January to December 1995 at Mexican Institute of Social Security. The instrument was designed with experts' contribution along different stages and validated using implicit criteria and factorial analysis. A case-control study was then conducted to evaluate the contribution of the quality of care to inability secondary to femoral fractures. C ases were 108 active workers with permanent inability secondary to femoral fracture; controls were 94 active workers with fracture of femur but no permanent inability. Logistic regression modeling was used to establish the association between quality of care and partial permanent inability, adjusting by relevant variables. Results. The ultimate indicator of quality of care consisted of the following: Timely care, presurgical management, surgical management, and fracture complications. A final score over 229 points meant that the worker had received good quality of care. W orkers getting 229 or less points had received poor quality of care. Forty-
\end{abstract}

\author{
Salinas-Tovar S, Reyes-Frausto S, \\ Aguilar-Salinas A, López-Marmolejo A, \\ Hernández-Leyva BE, López-Rojas $P$. \\ Efecto de la calidad de la atención médica \\ en los casos de fractura de fémur con incapacidad permanente \\ secundaria a accidentes de trabajo. \\ Salud Publica Mex 2001;43:108-112. \\ EI texto completo en inglés de este artículo está \\ disponible en: http://www.insp.mx/salud/index.html
}

\section{Resumen}

Objetivo. Construir y validar un indicador para evaluar la calidad de la atención en casos de fractura femoral, así como evaluar la contribución de la calidad de la atención como determinante de incapacidad parcial permanente, secundaria a fractur as femorales debidas a accidentes laborales. Material y métodos. El diseño del instrumento se hizo en varias etapas con la colaboración de expertos y se validó usando criterios implícitos y análisis factorial. El estudio fue de tipo casos y controles; los casos fueron 108 trabajadores activos, con incapacidad parcial permanente por fractura femoral, en tanto que los controles fueron 94 trabajadores activos con fractura femoral pero sin incapacidad parcial permanente. Se construyó un modelo de regresión logística para analizar la asociación entre la calidad de la atención y la incapacidad parcial permanente, ajustando por otras variables de importancia. Resultados. El indicador final de calidad de la atención se construyó con los siguientes factores: atención oportuna, manejo prequirúrgico, manejo quirúrgico y complicaciones. La calificación final mayor a 229 puntos se consideró como buena calidad de la atención y la de 229 o menos puntos, como mala. Cuarenta y ocho (44\%) casos y 66 (70\%) controles recibieron buena calidad de la atención. El riesgo de incapacidad

(1) Coordination of $O$ ccupational Health, Mexican Institute of Social Security (IMSS), México, D.F., México.

(2) Medical Research Unit on Ageing, Q uerétaro, Q ro., México. IMSS.

(3) Planning and Medical Infrastructure, IMSS, México, D.F., México. 
eight (44\%) cases and 66 (70\%) controls received go od quality of medical care. The likelihood of partial permanent inability was almost three times higher among workers given poor quality of care (O R 2.95; 95\% CI $1.5-5.5)$. According to the multivariate model, predictors of partial permanent inability were: Having exposed or epiphysiary fractures, being re-submitted to surgery, having less than 90 days of rehabilitation care, and receiving deficient medical care. Conclusions. The constructed instrument was validated. The level of the quality of care received by workers is a determining factor for the generation of partial permanent inability. In workers having femoral fractures, it is important to consider timely medical care and early rehabilitation, to reduce the high incidence and prevalence of this medical problem in Mexico. The English version of this paper is available to o at: http://www.insp.mx/salud/index.html

Key words: femoral fracture; quality of care; permanent disability; occupational accidents; Mexico parcial permanente fue casi tres veces mayor entre los trabajadores con mala calidad de la atención (RM 2.95; IC 95\% 1.5-5.5). El modelo multivariado mostró que la incapacidad parcial permanente se asoció con fracturas expuestas, fracturas epifisiarias, reenvío a cirugía, menos de 90 días de rehabilitación y atención médica deficiente. Conclusiones. Se validó el instrumento construido. El nivel de calidad de la atención recibida por los trabajadores es un factor determinante de incapacidad parcial permanente. En trabajadores con fracturas femorales la atención médica oportuna y la rehabilitación temprana reducen la alta incidencia y prevalencia de la incapacidad parcial permanente secundaria a accidentes de trabajo. El texto completo en inglés de este artículo también está disponible en: http://www.insp.mx/ salud/index.html

Palabras clave: fractura femoral; calidad de la atención; incapacidad permanente; accidentes laborales; México
E emoral fractures are among the five most frequent types of fractures due to occupational accidents. ${ }^{1-3}$ Based on their severity, they may cause death, temporary inability for working or lifetime inability. The latter may be due to limited or total loss of joint movement, hypotrophy, osteomyelitis, pseudoarthrosis, shortening of the diaphysis, and necrosis of the femoral head. It is noteworthy that cases herein reported occurred during or as a consequence of working, as defined by the Mexican Institute of Social Security (IMSS). Based on the type of fracture, the time needed for recovery may range between 70 and 336 days, often increasing due to factors associated with the quality of medical care and/or the patient's health status. It has been reported that the quality of medical care has an influence on femoral fracture time of evolution, generation of permanent sequela, and mortality. ${ }^{4-6}$ If the fracture was an occupational accident and additional complications occur, the worker is entitled to retiring with a pension. ${ }^{7,8}$

The assessment of the quality of medical care has been done using different methods. Based on the model of product supply, Donabedian has proposed three basic components of the quality of medical care: "structure", "process", and "outcomes". This model includes the analysis of factors pertaining to health care services, ${ }^{9,10}$ such as the scarcity of health care personnel, work overload, and insufficient time devoted to each patient's care. If the scarcity of personnel increases, there is a delay in medical care, leading to poorer physician motivation, to increased unplanned absenteeism, and to greater deterioration of the quality of medical care. ${ }^{11}$ At IMSS, ${ }^{12}$ the quality of medical care is defined as the attribute of both the elements and their organization to produce health care services and the outcomes obtained when managing health problems and what is obtained when the expected standards for reaching goals and objectives are achieved." Among the IMSS population, great regional variation in the proportion of people having partial permanent inability (PPI) has been identified (0-60\% depending on the State in Mexico) as a consequence of occupational accidents. This variation, as well as the period of recovery, could be explained by the quality of care, among other factors. ${ }^{13}$

The objectives of this study were: To construct and validate an indicator for evaluating the quality of care for femoral fractures, and to assess the contribution of the quality of care for patients with and without PPI due to occupational femoral fractures.

\section{Material and methods}

\section{Construction and validation of the instrument}

The data collection instrument was a questionnaire designed for assessing the quality of medical care with the participation of experts in trauma care. Items were assessed using a pilot test carried out at two tertiary level of care IMSS hospitals, using cases from 1994. The questionnaire was filled out with data abstracted from medical records. Questionnaires were scored in three 
levels of quality of care by adding values to questions. At the same time cases were evaluated by experts who assigned the level of quality of care through implicit criteria. The category in which each case was classified was the same in both types of evaluation. Reduction of variables into quality of care indicators was done by using factorial analysis. After factors were defined, scores were given and categories established.

\section{Case-control study}

Cases were included if they were active, insured, healthy workers, who had PPI as a consequence of an occupational femoral fracture, ipsilateral or ipsilateral acetabular fracture cases were excluded. Cases with incomplete data were eliminated. Controls were selected if they were active, insured, healthy workers, who had a femoral fracture without permanent partial inability (PPI).

The study was conducted from January to December 1995 in the Coordination of Occupational Health, Mexican Instituto of Social Security, Mexico, City. Patients were selected nationwide from IMSS general people work, Regional, and trauma hospitals wich had femoral fracture due job accident. The study population included 108 cases and 94 controls, after aplications the criteria of selection. The cases were the total of the workers insured in the IMSS that suffered fracture of femur in 1995 and that they were with permanent inability. The controls were the total of workers insured in the IMSS that suffered fracture of femur in 1995 and that they didnt present permanent inability. Data analysis consisted of descriptive statistics globally; with or without permanent inability were compared using chi squared. Odds ratios with $95 \%$ confidence intervals were calculated to evaluate the association with different variables. Variables statistically or conceptually associated with PPI in the crude analysis together with the variable concerning the quality of medical care were adjusted for to predict PPI using a logistic regression model.

\section{Results}

\section{Construction and validation of the instrument}

A total of 22 indicators were constructed using 83 items for measuring timely care, resources personnel, technical ability, process, and outcomes. After factorial analysis some items with non-significant correla- tion were eliminated and the rest of them were grouped into four factors: timely care, pre-surgical management, surgical management, and presence of complications. Factors and their scores are presented in Table I. Timely care was considered adequate when the score reached a level between 100-150, and inadequate when it was between 0-99. For both pre-surgical and surgical management, scores between 0-19 were considered inadequate, and those between 20-30 were considered adequate. Complications were absent with scores between 90-130 and present with scores between $0-89$. The quality of medical care was considered good with scores between $230-340$ points and poor with scores between 0-229.

Table I

Quality OF MEDical CARE INDicators FOR FEMORAL FRACTURES. MEXICAN INSTITUTE of Social Security, 1995

Factor 1: Timely Care

Time between admitting unit to treating unit

Time between admission to IMSS medical unit and start

of care at the treating unit

N umber of referrals within IMSS

$(0-30)$

Time between the accident and start of resolutive treatment ( 0-30)

Time between admission of patient and start of treatment $\quad(0-30)$

Factor 2: Pre-surgical Management

Preoperatory Tests

Fasting

$(0-15)$

Factor 3: Surgical Management

Surgical Technique

Factor 4: Complications

Superficial infection of the surgical wound

Deep infection of the surgical wound

$(0-20)$

Complications during surgery

Fat embolism

$(0-10)$

Pulmonary embolism

$(0-10)$

0 steomyelitis

$\frac{(0-30)}{(0-30)}$

Surgical reintervention

Source: Survey list of the assessment of medical charts 


\section{Factors explaining the presence of permanent partial inability}

Of the total number of cases, 410 medical records were integrated, but only 202 met the inclusion and exclusion criteria. The final count was 108 cases with PPI and 94 without PPI. Approximately $46 \%$ of these patients were seen at IMSS General Zone Hospitals, 33.7\% at Regional Hospitals, and $20.3 \%$ at Trauma Hospitals. A total of $92.5 \%$ of the patients were men and $7.5 \%$, women. About $41 \%$ were between $16-25$ years of age and $22.3 \%$ between $36-45$ years of age. The main occupations of study subjects were: General assistant $(21 \%)$, driver $(9 \%)$, messenger $(8 \%)$, and bricklayer $(7 \%)$. Based on the type of accident, $77.7 \%$ were at work and $22.3 \%$ on the way to or from work. Approximately $81.6 \%$ were non-exposed fractures and $18.4 \%$ exposed ones. The most frequent type of fractures was transverse simple fracture of the middle area $(25.2 \%)$, transtrocanteric $(10.9 \%)$, supracondile $(10.9 \%)$, and with wedge-shaped fragments in the subtrocanteric zone $(6.9 \%)$. A total of $96 \%$ of the patients required surgical treatment, with $61.3 \%$ of the surgeries done during the morning shift. In $39.3 \%$ of the cases, surgery lasted up to 2 hours, and in $47.4 \%$ up to 3 hours. Treatments most frequently applied were steel plates $(37.8 \%)$, central-shaft nails $(26.9 \%)$, and blocked nails $(11.4 \%)$. Complications occurred in $22.2 \%$ of the interventions; the most frequent were lack of osteosynthesis $(30.9 \%)$, and problems with the osteosynthetic material $(28.6 \%)$. A total of $26.6 \%$ of the patients were resubmitted to surgery mainly due to pseudoarthrosis $(26.4 \%)$, and infection $(20.7 \%)$. Only $14.9 \%$ of the patients were rehabilitated in the immediate post-surgery period. The length of hospital stay was 1-37 days (mean 12.4). The average recovery time from femoral fractures was 287.6 days (range 41-1000 days, SD 161.9).

Variables statistically associated with partial permanent inability were: male (OR 5.12, 95\% CI 1.2-23.7); exposed fracture (OR 3.95, 95\% CI 1.6-10); Epiphysiary fracture (OR 1.86, 95\% CI 0.9-3.6), total rehabilitation time 1-89 days (OR 2.53, 95\%CI 0.9-6.5) (Table II). As can be seen in Table III, $45 \%$ of the cases and $70 \%$ of the controls received good quality of care. Patients who received inadequate quality care (OR 2.95, 95\% CI 1.55-5.51) had more than two times of risk suffered PPI. Patients who suffered exposed fracture (OR 3.93 95\% CI 2;18-7.01); epiphysiary fractures (OR 1.03 95\% $\mathrm{CI} 0.56-2.03)$; that were newly subjected to surgery (OR $1.2095 \%$ CI 0.99-2.49), and given less than 90 days of rehabilitation (OR 1.007 95\% CI 0.61-1.81), in addition to receiving inadequate quality care (OR $2.3495 \% \mathrm{CI}$ 1.36-3.92), were at a greater risk to have PPI (Table IV).
Table II

Association of Quality OF MEdical CARE VARIABLES WITH FEMORAL FRACTURE PARTIAL PERMANENT INABILITY. Mexican Institute of Social Security, 1995

\begin{tabular}{|c|c|c|c|c|c|}
\hline \multirow[b]{2}{*}{ Variable } & Cases & \multicolumn{2}{|c|}{ Controls } & \multirow[b]{2}{*}{$O R$} & \multirow[b]{2}{*}{$\mathrm{Cl}(95 \%)$} \\
\hline & No. \% & No. & $\%$ & & \\
\hline \multicolumn{6}{|l|}{ Sex } \\
\hline Male & $105 \quad 97.2$ & 82 & 87.2 & 5.12 & $1.2-23.7$ \\
\hline Female & $3 \quad 2.8$ & 12 & 12.8 & - & - \\
\hline \multicolumn{6}{|l|}{ Type of Fracture } \\
\hline Exposed & 2926.8 & 8 & 8.5 & 3.95 & $1.6-10$ \\
\hline Closed & 7973.1 & 86 & 91.5 & - & - \\
\hline \multicolumn{6}{|c|}{ Classification of the Fracture } \\
\hline Epiphysiary & $42 \quad 38.9$ & 24 & 25.5 & 1.86 & $0.9-3.6$ \\
\hline Diaphysiary & $66 \quad 61.1$ & 70 & 74.5 & - & - \\
\hline \multicolumn{6}{|c|}{ Total Time to Rehabilitation } \\
\hline $1-89$ days & 5278.8 & 25 & 59.5 & 2.53 & $0.9-6.5$ \\
\hline 90-300 days & $14 \quad 21.2$ & 17 & 40.5 & - & - \\
\hline
\end{tabular}

Source: Survey list of the assessment of medical charts

Table III

Association between femoral fracture PERMANENT INABILITY AND QUALITY OF MEDICAL CARE INDICATORS. Mexican Institute of Social Security, 1995

\begin{tabular}{|c|c|c|c|c|}
\hline & Cases & Controls & & \\
\hline Indicator & $\begin{array}{l}\text { No. } \% \\
N=108\end{array}$ & $\begin{array}{l}\text { No. } \% \\
N=94\end{array}$ & $O R$ & $\mathrm{Cl}(95 \%)$ \\
\hline
\end{tabular}

O pportune Care

$\begin{array}{lllllll}\text { Inadequate } & 82 & 76 & 70 & 74 & 1.08 & 0.5-2.15 \\ \text { Adequate } & 26 & 24 & 24 & 26 & - & -\end{array}$

Preoperatory Management

\begin{tabular}{lrrrrrl} 
Inadequate & 9 & 8.3 & 3 & 3.1 & 2.76 & $0.6-13.3$ \\
\hline Adequate & 99 & 91.7 & 91 & 96.8 & - & -
\end{tabular}

0 peratory Management

\begin{tabular}{lllllll} 
Inadequate & 39 & 36.1 & 10 & 10.6 & 4.75 & $2.1-10.9$ \\
\hline Adequate & 69 & 63.8 & 84 & 89.3 & - & -
\end{tabular}

Presence of Complications

\begin{tabular}{rrrrrrl} 
Yes & 28 & 25.9 & 8 & 8.5 & 3.76 & $1.5-9.2$ \\
\hline No & 80 & 74.0 & 86 & 91.5 & - & -
\end{tabular}

Q uality of Medical Care

\begin{tabular}{lllllll} 
Poor & 60 & 55 & 28 & 30 & 2.95 & $1.5-5.5$ \\
\hline Good & 48 & 45 & 66 & 70 & - & -
\end{tabular}

Source: Survey list of the assessment of medical charts 
Table IV

\section{LOGISTIC REGRESSION MODEL TO PREDICT FEMORAL FRACTURE PERMANENT INABILITY, Mexican Institute of Social Security, 1995}

\begin{tabular}{llllr} 
Variable & Reference Category & OR & $P$-value & $95 \%$ Cl \\
Q uality of medical care & Poor & 2.34 & 0.022 & $1.36-3.92$ \\
\hline Type of fracture & Exposed & 3.93 & 0.001 & $2.18-7.01$ \\
\hline Cause of surgical reintervention & Insufficient osteosynthesis & 1.20 & 0.030 & $0.99-2.49$ \\
\hline Classification of fracture & Ephiphysiary & 1.03 & 0.027 & $0.56-2.03$ \\
\hline Total rehabilitation time & $<90$ days & 1.007 & 0.018 & $0.61-1.81$
\end{tabular}

Source: Survey list of the assessment of medical charts

\section{Discussion}

The technical ability of medical personnel, associated to an adequate work organization, are factors that influence the quality of the service provided. Based on the study conducted by Parker and cols. ${ }^{14,15}$ in 1994, a specific surgical group was gathered for the management of hip fractures. This group obtained a decrease in greater complications from $12 \%$ to $5 \%$, as well as in the number hospital stay days. In this study the incidence of complications and the number of days of hospitalization were higher, indicating a need for increasing and improving the training of personnel in the medical-surgical management of femoral fractures, in addition to providing the proper equipment and instrumentation necessary for their care.

Cameron ${ }^{16}$ reported that giving timely rehabilitation the length of stay decreased by $20 \%$. The latter cannot be achieved if there is a lack of physical therapy and rehabilitation physicians, as well as medical supplies, facilities, and specific equipment. As a conclusion, the quality of medical care is a determining factor for the occurrence of PPI among workers with femoral fractures, for whom it is necessary to regulate the surgical medical care of this condition and establish treatment protocols for early and timely medical care. ${ }^{16,17}$ At the beginning of the proposed methodology, obtained an objective rate of 6.8 , which permit to put the quality of medical attention of femoral fracture in workers as regular quality. In the medical literature, we do not identify quality objective to health problems and less associate to the quality of the proporcionated attention and permanent inability, as well as in this survey. The obtained qualification is a significant parameter that allows authorities established tendent measures to improve of the quality of the attention in workers who suffered femoral fracture to low the probability of PPI.

\section{References}

1. Hunting KL, N essel-Stephens L, Sanford S, Shesser R, W elch L. Surveillance of construction worker injuries through an urban emergency department. J 0 ccup Med 1994; 36: 356-364.

2. Hamlet W P, Lieberman JR, Freedman EL, D orey FJ, Johnson EE. The influence of health status and the timing of surgery on mortality in hip fracture patients. Am J 0 rthop 1997; 26: 621-632.

3. Bray TJ. Femoral neck fracture fixation. Clinical decision making. Clinic Orthop 1997;(339):20-31.

4. Starr AJ, H unt JL, Chanson D P, Reinert CM, W alker J. Treatment of femoral fracture with associated head injury. J 0 rthop Trauma 1998;12:38-45. 5. Ponce de León J, Herrera RH, Márquez TM. Tiempos aproximados de curación de las lesiones traumáticas. México, D.F.: Instituto Mexicano del Seguro Social, 1985:13-16.

6. Belville R, Pollack SH, Godbold JH, Landrigan PJ. O ccupational injuries among working adolescents. N ueva York: JAMA 1993;21:27-54.

7. Instituto Mexicano del Seguro Social. Ley del Seguro Social. México, D.F.: IMSS, 1995:77-78.

8. Secretaría del Trabajo y Previsión Social. Ley Federal del Trabajo. México, D.F.: STPS, 1982: 99-136.

9. Yoshida K. Revisiting Deming's 14 points in light of Japanese business practices: Q uali Management J 1944;Fall.14-42.

10. D onabedian A. La calidad de la atención médica. D efinición y métodos de evaluación. México, D.F.: La Prensa Médica Mexicana, 1991: 3-7.

11. Calderón F. Atención prioritaria a los trabajadores. Rev Med Inst Mex Seguro Soc 1993;31(31 Suppl 1);63-74.

12. Treviño GMN . Modelo de Atención a la Salud. Rev Med Inst Mex Seguro Soc 1994;(32supl.1):3-34.

13. Instituto Mexicano del Seguro Social. Anuario Estadístico. México, D.F.: IMSS,1994:18-27.

14. Samir MF. Incidence, management, and outcome of femoral shaft fracture: A state-wide population-based analysis of 2085 patients in a rural state. Trauma 1994;37 (2)255-265.

15. Parker MJ, Pryor GA, Myles JW. The value of special surgical team in preventing complications in the treatment of hip fractures. Int 0 rthop 1994;18:184-188.

16.C ameron ID, Lyle DM, Q uine S. Accelerated rehabilitation after proximal femoral-fracture: A randomized controlled trial. Disabil- Rehabil 1993;15:29-34.

17. Ethans KD, MacKnight $C$. Hip fracture in the elderly. An interdisciplinary team approach to rehabilitation. Postgrad Med 1998;103:167-170. 